\title{
Bioactive compounds in garlic (Allium sativum $L$.) as a source of antioxidants and its potential to improve the immune system: a review
}

\author{
*Subroto, E., Cahyana, Y., Tensiska, Mahani, Filianty, F., Lembong, E., Wulandari, E., \\ Kurniati, D., Saputra, R.A. and Faturachman, F. \\ Department of Food Industrial Technology, Faculty of Agro-Industrial Technology, Universitas \\ Padjadjaran, Jl.Raya Bandung-Sumedang Km. 21, Jatinangor, Sumedang 40600, Indonesia
}

Article history:
Received: 2 February 2021
Received in revised form: 4
March 2021
Accepted: 21 April 2021
Available Online: 26
September 2021
Keywords:
Garlic,
Bioactive compound,
Antioxidant,
Organosulfur,
Immune system
DoI:
https://doi.org/10.26656/fr.2017.5(6).042

\begin{abstract}
Garlic (Allium sativum L.) is a type of spice derived from layered tubers, widely used as a source of flavour, taste, and cooking spices. Garlic is a therapeutic ingredient rich in bioactive compounds and antioxidants. The purpose of compiling this review is to provide information about bioactive compounds in garlic as a source of bioactive compounds and their potential to improve the immune system. This review also discussed the various effects of garlic processing on the stability and activity of bioactive compounds and the changes that occur during storage. Garlic contains high levels of organosulfur compounds, micronutrient selenium (Se), and flavonoids. The bioactive compounds in garlic are generally extracted using ethanol as a solvent. Food processing treatments such as boiling, frying, and others can have a positive impact on the organosulfur compounds. Organosulfur levels correlate with changes in antioxidant capacity and activity. The bioactive compounds of garlic can potentially boost the immune system or act as immunostimulants.
\end{abstract}

\section{Introduction}

Garlic is the second most common Allium plant grown in the world after shallots. Garlic has been consumed and used widely in the food and pharmaceutical industries in fresh or dried garlic. Garlic is used as a source of flavour, aroma, and taste or spice for other food processing (Pokorný et al., 2001). The properties of garlic have been widely studied as a therapeutic ingredient such as antibacterial, antiviral, anti -fungal, anti-thrombotic, antibiotic, anticancer, antioxidant, immunomodulatory, anti-inflammatory, and hypoglycemic effect (Rizwani and Shareef, 2011; Fesseha and Goa, 2019; Batiha et al., 2020).

Garlic contains various bioactive compounds, especially in the form of organosulfur compounds and phenolic compounds. The phenolic compounds from garlic have one or more hydroxyl groups that act as hydrogen donors to neutralize free radicals (antioxidants). Antioxidants have been shown to safeguard the body from the effects of reactive oxygen species (ROS) and free radicals. ROS consists of several compounds, including hydrogen peroxide $\left(\mathrm{H}_{2} \mathrm{O}_{2}\right)$, superoxide anions $\left(\mathrm{O}_{2^{*}}\right)$, peroxyl (ROO-), hydroxyl ($\mathrm{OH}$ ), and alkoxyl (RO-) radicals are compound groups that will oxidize proteins, lipids, and DNA damage causing diseases (Sharma et al., 2012; Abdel-Gawad et al., 2014; Collin, 2019). Organosulfur and phenolic compounds as antioxidants in garlic play an important role in preventing cell and organ damage from the oxidation process (Capasso, 2013; Abdel-Gawad et al., 2014).

The antioxidant activity of bioactive compounds in vegetables and fruits, including garlic, can be affected by some factors such as processing and storage, presence of food additives, and interactions with other nutrients (Nicoli et al., 1999; Cardelle-Cobas et al., 2005; Pedraza -Chaverrí et al., 2007). For example, thermal processes can decrease or even increase antioxidant activity depending on whether the polyphenol antioxidant compounds are degraded or the formation of antioxidant products as a result of the release of aglycones and the Maillard reaction formed during the process and storage (Yilmaz and Toledo, 2005; Indiarto et al., 2019). The main aim of this review is to summarize the various effects of processing and storage of garlic on the stability and activity of its bioactive compounds, and the role of these compounds to enhance the immune system.

\section{Bioactive compounds and antioxidants in garlic}

The bioactive compounds in garlic are mostly 
derived from sulfur-containing compounds and their precursors. These compounds include Allicin, Diallyl sulfide (DAS), Diallyl trisulphide (DATS), Diallyl disulfide (DADS), Ajoene, and 2-Vinyldithiins, which are the main antioxidant compounds and also contribute to important biological activity for garlic (Shang et al., 2019). Besides, the antioxidant activity of these compounds also correlates with other bioactive compounds such as bioactive peptides, dietary fibre, polyphenols, and micronutrients (especially $\mathrm{Se}$ ) (Capasso, 2013). This is in line with research conducted by Nencini et al. (2011), in addition to containing bioactive organosulfur compounds, garlic also contains flavonoids and polyphenols, which are potential antioxidant agents. These organosulfur compounds can also be produced during the cooking process of garlic, distillation, and storage of garlic extract (Weinberg et al., 1993; Yu et al., 1993, Yu et al., 1994; Kamel and Saleh, 2000). The bioactive organosulfur compounds in garlic can be seen in Figure 1.

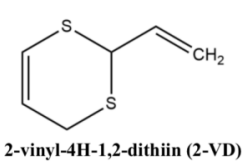

2-vinyl-4H-1,2-dithiin (2-VD)
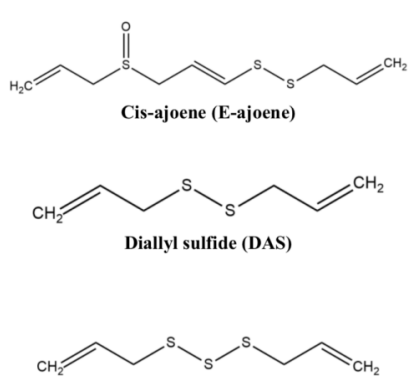

Diallyl trisulphide (DATS)
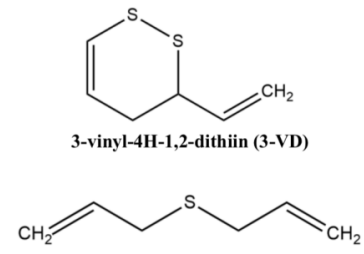
Diallyl disulfide (DADS)

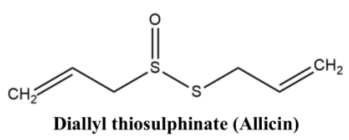

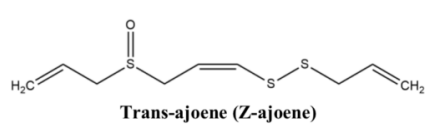

Figure 1. The organosulfur compounds that are bioactive in garlic

Organosulfur compounds are compounds produced from the synthesis of sulfates derived from plant roots, which absorb nutrients or nutrients from the soil and make them the main source of sulfur. The organosulfur compounds then transform into other derivative compounds (Omar and Al-Wabel, 2010). The first functional group is produced when the garlic tissue damaged is thiosulfinate, and allicin is one of the most dominant compounds present in it. These compounds provide a distinctive pungency effect on garlic when processed/consumed (Locatelli et al., 2015). Garlic contains organosulfur compounds that tend to undergo a biological transformation or are unstable, but it turns out that there is also a group of organosulfur compounds, namely polysulfides, which are the most stable of all because these compounds are the final compound product of the transformation (Ramirez et al., 2017; Shang et al., 2019).

\section{Extraction method of bioactive compounds from garlic}

In general, the extraction process for bioactive compounds and antioxidants in garlic can be performed by maceration using ethanol as a solvent. The choice of ethanol as the solvent was due to the ability of ethanol to attract the active ingredients in the extract better than other solvents, easy to obtain, and relatively cheap (Rahmawati et al., 2019). The extraction process can be used in various kinds of solvents other than ethanol, including distilled water, petroleum ether, ethyl acetate, hexane, chloroform, and methanol (Kim and Cheong, 2015). However, garlic extraction using ethanol solvent resulted in higher antioxidant activity than other solvents (Durairaj et al., 2009).

The method for determining the antioxidant activity of garlic can use the DPPH test method (1,1-diphenyl-2picrylhydrazyl) (Prasonto et al., 2017). DPPH is a free radical. The reaction of DPPH with antioxidants by electron transfer or hydrogen radicals will neutralize DPPH that has character as free radical (Molyneux, 2004). Some of the advantages of this method are that it is fast, simple, and requires simple tools. The lower the $\mathrm{IC}_{50}$ value from the DPPH antioxidant activity test, the substance/material will have high antioxidant properties (Gupta, 2015).

The extraction by maceration method is often chosen because this method is simple, has been widely used in the extraction of herbal plants, and is suitable for use in thermolabile compounds such as garlic. Ethanol solvent was chosen because it has a high polarity to extract more material than other types of organic solvents and has a low boiling point (Handa et al., 2008; Rahmawati et al., 2019). However, apart from maceration, there are several extraction methods for bioactive compounds in garlic that can be an alternative choice, including high-pressure extraction, supercritical fluid extraction, ultrasoundassisted extraction (UAE), magnetic solid-phase extraction (MSPE), subcritical water extraction (SWE), hydrolytic enzymes extraction, salting-out extraction, and others as shown in Table 1.

\section{Mode of action of bioactive compounds and antioxidants on garlic}

The reaction of free radical scavenging by bioactive compounds in garlic can occur through several mechanisms. Garlic extract, especially from organosulfur compounds, stimulates the activity of glutathione peroxidase (GPX) and inhibits the decrease in the ratio of reduced to oxidized glutathione. GPX activity has also increased with the presence of diallyl disulfide (DADS) and diallyl sulfide (DAS). These compounds increase 
Table 1. Various methods of extraction of bioactive compounds from garlic

\begin{tabular}{|c|c|c|}
\hline Extraction Methods & Conditions or Results & References \\
\hline \multirow[b]{2}{*}{ Maceration } & Extraction of cycloalliin was optimum at $80^{\circ} \mathrm{C}, \mathrm{pH} 10$ for $12 \mathrm{hrs}$ & Lee et al. (2016) \\
\hline & $\begin{array}{l}\text { Garlic bioactive compounds could be extracted effectively with ethanol } \\
\text { and water as a solvent }\end{array}$ & Rahmawati et al. (2019 \\
\hline $\begin{array}{l}\text { High pressure } \\
\text { extraction }\end{array}$ & $\begin{array}{l}\text { High pressure extraction led to higher yields of hydrophilic compounds } \\
\text { than maceration. }\end{array}$ & Ferioli et al. (2020) \\
\hline $\begin{array}{l}\text { Magnetic solid phase } \\
\text { extraction (MSPE) }\end{array}$ & $\begin{array}{l}\text { MSPE is effective for the extraction of bioactive peptides from garlic and } \\
\text { removes } 80 \% \text { of impurities }\end{array}$ & Yu et al. (2020) \\
\hline $\begin{array}{l}\text { Ultrasound-assisted } \\
\text { extraction (UAE) }\end{array}$ & $\begin{array}{l}\text { UAE was effective for the extraction of phenolic compounds from garlic, } \\
\text { optimum at a temperature of } 59^{\circ} \mathrm{C} \text { for } 13.5 \text { mins. }\end{array}$ & Ciric et al. (2020) \\
\hline $\begin{array}{l}\text { Supercritical fluid } \\
\text { extraction (SFE) }\end{array}$ & $\begin{array}{l}\text { SFE was effective for the extraction of phenolic compounds from garlic, } \\
\text { optimum at a temperature of } 50^{\circ} \mathrm{C} \text { for } 9 \text { mins by the addition of } 30 \%\end{array}$ & Liu et al. (2018) \\
\hline $\begin{array}{l}\text { Subcritical water } \\
\text { extraction (SWE) }\end{array}$ & $\begin{array}{l}\text { The extraction of phenolic compounds from garlic was optimum at a } \\
\text { temperature of } 180.92^{\circ} \mathrm{C} \text { for } 10 \text { mins by the addition of an acidifier of }\end{array}$ & Tomšik et al. (2017) \\
\hline $\begin{array}{l}\text { Hydrolytic enzymes } \\
\text { extraction }\end{array}$ & Cycloalliin increased 1.5 times than non-enzymatic extraction. & Lee et al. (2013) \\
\hline $\begin{array}{l}\text { Steam explosion } \\
\text { extraction }\end{array}$ & $\begin{array}{l}\text { Steam explosion significantly increased the antioxidant activity of raw } \\
\text { garlic extract, optimal conditions at a steam pressure of } 45 \text { atm for } 5 \\
\text { mins. }\end{array}$ & Noda et al. (2013) \\
\hline Salting-out extraction & $\begin{array}{l}\text { The optimum conditions for Allicin extraction were at an ethanol } \\
\text { concentration of } 23 \% \text {, salt concentration of } 24 \% \text {, and loaded sample of } 31\end{array}$ & Li et al. (2017) \\
\hline
\end{tabular}

glutathione reductase activity and increase superoxide dismutase activity, while S-allylcysteine (SAC) and SAllylmercaptosysteine (SAMC) increase reduced glutathione (GSH) synthesis. Old garlic extract, SAMC, and SAC showed radical scavenging activity, while DADS and DAS demonstrated selective action on diverse markers in testing their capability to react with free radical carbon tetrachloride. DADS also inhibits carbon tetrachloride-induced lipid peroxidation. Hence, the antioxidant properties of garlic may result from the contribution of various sulfur components at different process steps (Omar and Al-Wabel, 2010).

The antioxidant activity of bioactive compounds in garlic can be conducted in vitro by extracting garlic using $15 \%$ Hydroethanol solvent soaked for more than 20 months or commonly referred to as Aged Garlic Extract (AGE). AGE has the best antioxidant activity compared to extraction by direct cutting or commonly known as raw garlic extract (RGE), or heated, called heated garlic extract (HGE) using solvents other than 15\% Hydroethanol (Capasso, 2013). The antioxidant activity of natural compounds derived from garlic, such as flavonoids, is caused by hydroxyl groups in the molecular structure. Flavonoids are polyphenolic compounds in several plants such as tea, vegetables, fruits, grapes, and onions. The antioxidant activity of flavonoids depends on their molecular structure, especially the prenyl group $\left(\mathrm{CH}_{3}\right)_{2} \mathrm{C}=\mathrm{CH}-\mathrm{CH}_{2}-$. Prenyl flavonoid groups have been developed and proven to play a role in the prevention or therapy of diseases associated with free radicals (Gutierrez et al., 2014; Santos and Silva, 2020).
The flavonoid conjugation pathway begins with the conjugation of mutant glucuronides in the cells of the small intestine. Flavonoids are bound to albumin and transported to the liver, then conjugate with sulfate groups, methyl groups, or both. The addition of these groups will increase circulation clearance and also reduce toxicity. Several studies have shown that flavonoid conjugation can inhibit xanthine oxidase enzyme activity and increase antioxidant activity (Ponce et al., 2000; Lin et al., 2015).

Nevertheless, there is some debate about the toxic and mutagenic properties of flavonoid quercetin. Formica and Regelson (1995) conducted in vivo and in vitro studies on quercetin and found toxic side effects in vitro. Dunnick and Halley (1992) stated that a high intake of quercetin, taken for several years in mice, will cause tumours. However, none of the long-term studies was found to be carcinogenic. This research continues to be conducted on the mutagenic effects of flavonoids, showing that flavonoids containing quercetin are antimutagenic in vivo. Clinical research by Kneck et al. (2014) on women and men (24 years) states that more intake of flavonoids (quercetin) results in lower cancer risk. Flavonoids are toxic to cancer cells but not toxic to normal cells so that flavonoids can be used in cancer prevention.

Primary antioxidants such as flavonoids at low concentrations are known to inhibit oxidation reactions or scavenge free radicals. However, too high a concentration can affect the rate of oxidation. At high concentrations, the antioxidant activity of the phenolic 
group is often lost; even the antioxidants become prooxidants (Sotler et al., 2019). The effect of total concentration on the oxidation rate depends on the antioxidant structure, conditions, and the sample to be tested (Apak et al., 2007; Shahidi and Zhong, 2015).

\section{Various treatments and processing on garlic and their effect on antioxidant activity}

Consumption of garlic by the world community is now increasingly diverse, either through direct consumption of fresh garlic or through processing processes such as frying, drying, or used as cooking spices. These processes can certainly affect the content of antioxidant compounds and their activity. These changes can also be influenced by the addition of other food additives during processing or even by interactions with other nutrient components (Queiroz et al., 2009). Various treatments of garlic and their effects on the bioactive compounds can be seen in Table 2 .

Locatelli et al. (2017) performed a study regarding the antioxidant characteristics of fresh garlic with cooked garlic and proved whether cooked garlic can still be regarded as a healthy food. There was a significant rise in the profile of organosulfur compounds at the precooking and cooking stages compared to the control. Allicin with the highest concentration was obtained in chopped garlic, treated by boiling using water as the heat transfer medium. In contrast, the concentration of ajoene compounds in the pre-cooking stage was smaller than when the cooking treatment was carried out, which increased the DADS and DATS concentrations. This is caused by the presence of non-polar solvents, such as vegetable oils that support decomposition or change into other organosulfur compounds at high temperatures (Ilić et al., 2012). Organosulfur compounds such as Ajoene have increased, where the highest concentration of Ajoene is found in chopped garlic cooked in stir-frying with the non-polar vegetable oil medium. This is also seen in the high 2-Vinyldithiins in the treatment (Locatelli et al., 2015). Previous research conducted by $\mathrm{Yu}$ et al. (1993) also showed that the Thiosulfinate compounds in garlic could turn into other organosulfur compounds, namely DADS, whose changes are directly proportional to the increase in cooking temperature. This also proves that the cooking treatment of garlic has a positive biological impact on the presence of the organosulfur compounds it contains.

Other organosulfur compounds in the form of allicin have different characteristics. The greater the concentration of allicin can spur oxidation, where previous research found that organosulfur compounds can act as pro-oxidants under certain conditions (Sotler

Table 2. Various treatments of garlic and their effects on the bioactive compounds and antioxidant activity

\begin{tabular}{|c|c|c|c|}
\hline $\begin{array}{l}\text { Treatments/ } \\
\text { processing }\end{array}$ & Treatment conditions & Results & References \\
\hline \multirow{2}{*}{ Heating } & $\begin{array}{l}\text { Garlic is boiled and fried until the } \\
\text { color changes. }\end{array}$ & $\begin{array}{l}\text { The highest allicin content is in garlic without heating } \\
\text { treatment. However, heating can still maintain the }\end{array}$ & $\begin{array}{l}\text { Locatelli et } \\
\text { al. (2017) }\end{array}$ \\
\hline & $\begin{array}{l}\text { Heating of garlic using different } \\
\text { temperature and photoperiod }\end{array}$ & $\begin{array}{l}\text { The optimal heating to produce the highest allicin is a } \\
\text { photoperiod of } 14 \text { hours and a temperature of } 25^{\circ} \mathrm{C} \text { at }\end{array}$ & $\begin{array}{l}\text { Atif et al. } \\
(2020)\end{array}$ \\
\hline Blanching & $\begin{array}{l}\text { Infrared dry blanching }\left(\mathrm{T}=95-135^{\circ}\right. \\
\mathrm{C}, \mathrm{t}=20 \mathrm{~min})\end{array}$ & $\begin{array}{l}\text { Peroxidase decreased with increasing temperature and } \\
\text { the slice thickness of garlic. Infrared dry blanching } \\
\text { produced better garlic quality than water blanching, }\end{array}$ & $\begin{array}{l}\text { Feng et al. } \\
\quad(2018)\end{array}$ \\
\hline \multirow{3}{*}{ Storage } & $\begin{array}{l}\text { Storage in a solution of } 5 \% \text { acetic } \\
\text { acid, water, phosphoric acid, oxalic } \\
\text { acid, malic acid, citric acid, and HCL } \\
(\mathrm{t}=7 \text { days })\end{array}$ & $\begin{array}{l}\text { Storage of acetic acid shows a greenish color change } \\
\text { due to the degradation reaction of Allium to produce S- } \\
\text { alk(en)ylcysteine sulfoxides. Storage at low } \\
\text { temperatures can inhibit this degradation. }\end{array}$ & $\begin{array}{l}\text { Zang et al. } \\
\quad(2013)\end{array}$ \\
\hline & $\begin{array}{l}\text { Storage of garlic bulbs with } \gamma- \\
\text { irradiated }\end{array}$ & $\begin{array}{l}\text { Garlic irradiated } 0.12 \mathrm{kGy} \text { produced the best quality } \\
\text { and minimum weight loss }\end{array}$ & $\begin{array}{l}\text { Sharma et al. } \\
\text { (2020) }\end{array}$ \\
\hline & $\begin{array}{l}\text { Irradiation with } \gamma \text {-irradiation }(0-2.5 \\
\mathrm{kGy}) \text { during packaging on garlic } \\
\text { stored in the refrigerator. }\end{array}$ & $\begin{array}{l}1.5 \text { kGy gamma-ray irradiation with polypropylene } \\
\text { packaging produces the best quality garlic and lasts } 77 \\
\text { days. }\end{array}$ & $\begin{array}{l}\text { Sharma et al. } \\
\text { (2021) }\end{array}$ \\
\hline Marination & Marination of garlic & $\begin{array}{l}\text { Marinated garlic has a higher allicin content than non- } \\
\text { marinated garlic }\end{array}$ & $\begin{array}{l}\text { Ricciutelli et } \\
\text { al. (2020) }\end{array}$ \\
\hline \multirow[b]{2}{*}{ Drying } & $\begin{array}{l}\text { Drying by relative humidity drying, } \\
\text { infrared hot air drying, vacuum freeze } \\
\text {-drying, and pulsed vacuum drying }\end{array}$ & $\begin{array}{l}\text { The treatment of Infrared radiation heating and relative } \\
\text { humidity drying on garlic produced higher allicin } \\
\text { content than other treatments. }\end{array}$ & $\begin{array}{l}\text { Feng et al. } \\
\quad(2020)\end{array}$ \\
\hline & $\begin{array}{l}\text { Pretreatment of dried garlic slices } \\
\text { through vacuum-assisted } \\
\text { osmosonication, osmosonication, and } \\
\text { sonication. }\end{array}$ & $\begin{array}{l}\text { Vacuum-assisted osmosonication produces garlic with } \\
\text { the best quality and physicochemical properties. }\end{array}$ & $\begin{array}{l}\text { Alolga et al. } \\
\text { (2020) }\end{array}$ \\
\hline
\end{tabular}


et al., 2019). Pro-oxidants are chemical compounds that induce oxidative stress by hindering the work of the antioxidants themselves or producing ROS (Rahal et al., 2014). Besides, this compound also has redox potential where it can be oxidized by ROS and then phenolic compounds as potential antioxidants will be consumed, so that antioxidants demote the antioxidant part of the total extract or can be called an antagonistic effect (González and Nazareno, 2011; Sotler et al., 2019).

In general, polysulfides in the form of DAS, DADS, and DATS are organosulfur compounds with low antioxidant activity. This polysulfide is unable to form sulfenic acid. However, Higuchi et al. (2003) stated that DATS has antioxidant activity that can inhibit the conformation of lipid hydroperoxide in LDL. It is caused by the unbonded electrons linked to the double bonds in sulfur, which could increase antioxidant activity. That matter is affected by the number of sulfur atoms in the molecule because disulfides show lower activity than trisulfides (Higuchi et al., 2003; Fernandes et al., 2020). Ajoenes and Vinyldithiins are also known to have high antioxidant activity. These compounds have a double bond that is correlated with an unpaired electron in sulfur, which can increase the antioxidant activity, including the presence of sulfur with conjugated unpaired electrons in the double bond ring system found in the compound 2-Vinyldithiin (Batiha et al., 2020).

The bioactive compounds in garlic can also change storage. These changes can be affected by several factors, including storage time, cultivar, storage temperature, and others (Sekara et al., 2017). Determination of changes in antioxidant activity in garlic during storage can be tested by the DPPH and FRAP methods. Fei et al. (2015) showed that the antioxidant activity of garlic decreased significantly during storage for 12 days. However, the antioxidant capacity of garlic extract using ethyl acetate was higher than extraction using ethanol and $\mathrm{H}_{2} \mathrm{O}$.

Changes in the chemical structure and biosynthetic pathways in the metabolic processes of garlic have complex mechanism. Some of the things that have received a lot of attention from researchers are studying the content of biologically significant substances, identification, purification, and separation. Parisi et al. (2008) stated that the dual function protein with a molecular weight of $25-26 \mathrm{kDa}$ isolated from garlic showed proteolytic activity and hemagglutination. Hadji et al. (2007) showed that Mn-superoxide dismutase and $\mathrm{Zn}, \mathrm{Cu}$ superoxide dismutase are contained in fresh garlic in the form of SOD3, SOD2, and SOD1. Ichikawa et al. (2006) reported that organosulfur compounds play a very large role in the health benefits of garlic. The analytical method developed is through simple and fast sample preparation but is accurate in determining four sulfoxides in garlic and three glutamyl peptides. Research on the anticancer properties of garlic is also being studied, especially about the speciation of selenium in garlic (Dumont et al., 2006).

Storage has a significant effect on changes in dissolved sugar levels, antioxidant capacity, organosulfur compounds, and total polyphenols of garlic extract (Dillon et al., 2003). The garlic extract from ethyl acetate resulted in the 18 distinctive organosulfur compounds, the 10 compounds embroiled in DADS, DAS, and DATS achieved their optimum levels at 6-8 weeks. Eighteen organosulfur compounds that are unique to garlic were found when garlic was extracted using ethyl acetate. Then it was found that the compounds embroiled in DATS, DADS, and DAS achieved their optimum levels at six weeks. At the same time, the strongest antioxidant capacity is found at eight weeks of storage. DATS, DADS, and DAS extracted from long-stored garlic displayed high antioxidant capacity and suppressed the oxidation of LDL (Dillon et al., 2003). The polyphenol content in garlic correlates directly with antioxidant activity. Levels of organosulfur compounds with AMDS, AMS, DATTS, DATS, DADS, DAS, 6-(methylthio) hexa-1,5-dien-3-ol also correlated with alteration in antioxidant capacity (Nencini et al., 2011).

\section{The potential of garlic to improve the immune system}

Bioactive compounds in food can come from (i) bioactive compounds that already exist from one or several food components, (ii) bioactive compounds resulted from reactions during storage and processing, (iii) bioactive compounds that are added to food as a food additive. Antioxidants and natural bioactive compounds from plants are generally phenolic compounds from the flavonoid group, tocopherol, coumarin, cinnamic acid derivatives, and polyphenolic organic acids. The flavonoid groups that have antioxidant activity include catechins, isoflavones, flavonols, flavones, flavonoids, and chalcones (Kumar and Pandey, 2013; Panche et al., 2016). These compounds have an important role in health and can increase the immune system. It has been previously explained that garlic (Allium sativum L.) contains many antioxidant and bioactive compounds from the organosulfur and flavonoid groups. Therefore, garlic has the potential to increase the immune system when consumed either directly in the form of fresh and processed garlic or in the form of extracts of bioactive compounds.

The immune system is the most important part of the 
body's defence system. Efforts to increase the immune system in the body are very important to maintain it optimally. Increasing the body's defence system can be conducted by giving immunostimulants. Immunostimulants are a way to increase the immune system by using ingredients that can stimulate the immune system, which can come from various bioactive compounds from food (Vaseeharan and Thaya, 2014; Catanzaro et al., 2018; Rezaharsamto and Subroto, 2019). The immune system in the body responds to the entry of bacteria and viruses into the human body through a very complex mechanism. This immune system recognizes molecules (antigens) that are unique to bacteria or viruses that stimulate the production of antibodies, a type of protein, and a type of white blood cell called lymphocytes. These lymphocytes mark the incoming antigen and then destroy it. Thus, the immune system is the human body's mechanism to fight or expel foreign objects that enter their bodies in the form of bacteria or viruses (Catanzaro et al., 2018; Subroto and Indiarto, 2020).

The bioactive compounds in garlic, especially flavonoids, can play a role in increasing the body's defence system as immunostimulants. Flavonoids can increase the body's defence system because they can increase the production of IL-2, which is involved in the activation and proliferation of lymphocytes (Tsai et al., 2011), and can influence CD4 + cells, then thus resulting in Th1 cells being activated. Activated Th1 cells will influence SMAF (specific macrophage activating factor), which is multiple molecules, including IFN $\gamma$, which can activate macrophages (Ulfah et al., 2017; Hosseinzade et al., 2019).

In addition to flavonoid compounds, garlic also contains organosulfur compounds, which are bioactive and can play a role in boosting the immune system. The effect of the intake of organosulfur components has been proven epidemiologically and experimentally on the treatment and prevention of cancer (Omar and Al-Wabel, 2010). However, how the mechanism selectively selects between neoplasmic cells and normal cells is not certain. The mechanism of anticancer action of organosulfur compounds and flavonoids from garlic, in general, can be through the mechanism of regulating cell proliferation, inhibiting angiogenesis, altering mitochondrial permeability, and increasing antioxidant properties and proapoptosis (De Greef et al., 2020). The target molecules that are important in cancer prevention and therapy are enzymes that play a role in metabolism, transport, and repair, which strongly influence cell death, proliferation, and metastatic formation. Thus, the effect is not limited to the program of cell death but is also related to immune response and inflammatory processes
(Elmore, 2007; Phan et al., 2014).

Related to the potential of garlic in increasing the immune system in the body is that the content of bioactive compounds found in garlic is proven to increase the immune system, defense, or immunity, with its properties as an immunostimulant. Immunostimulants in garlic can be a potential alternative in dealing with the Covid 19 pandemic, which is still ongoing today. However, it is necessary to do further studies related to differences in clinical effectiveness and strength of the immune system produced by each individual and how the role of each bioactive compound in garlic in acting as immunostimulants to stimulate the body's immune system.

\section{Conclusion}

Garlic is a therapeutic agent that can act as an antibacterial, antiviral, anti-fungal, anti-thrombotic, antibiotic, anti-cancer, antioxidant, immunomodulatory, anti-inflammatory, and hypoglycemic effect. The greatest antioxidant activity in garlic comes from compounds containing sulfur and its precursors, including allicin, 2-Vinyldithiins, ajoenes, diallyl disulfide (DADS), diallyl trisulfide (DATS), and diallyl sulfide (DAS). The cooking treatment of garlic has a positive biological impact on the presence of the organosulfur compounds it contains. The cooking process, which increased the highest concentration of bioactive compounds, was stir-frying, followed by the boiling process. Organosulfur ajoenes and 2Vinyldithiins are known to have the highest antioxidant activity in garlic. The bioactive compounds in garlic have immunostimulant activity that needs further investigation so they can potentially increase the immune system.

\section{Conflict of interest}

The author declared no conflict of interest.

\section{Acknowledgments}

The authors would like to thank the Rector of Universitas Padjadjaran and the Ministry of Education, Culture, Research, and Technology of the Republic of Indonesia for the support provided.

\section{References}

Abdel-Gawad, M., Abdel-Aziz, M., El-Sayed, M., ElWakil, E. and Abdel-Lateef, E. (2014). In Vitro Antioxidant, Total Phenolic and Flavonoid Contents of Six Allium Species Growing in Egypt. Journal of Microbiology, Biotechnology and Food Sciences, 3 
(4), 343-346.

Alolga, R.N., Osae, R., Essilfie, G., Saalia, F.K., Akaba, S. and Chikari, F. (2020). Sonication, osmosonication and vacuum-assisted osmosonication pretreatment of Ghanaian garlic slices: Effect on physicochemical properties and quality characteristics. Food Chemistry, 343, 128535. https://doi.org/https://doi.org/10.1016/ j.foodchem.2020.128535

Apak, R., Güçlü, K., Demirata, B., Ozyürek, M., Celik, S.E., Bektaşoğlu, B., Berker, K.I. and Ozyurt, D. (2007). Comparative evaluation of various total antioxidant capacity assays applied to phenolic compounds with the CUPRAC assay. Molecules, 12 (7), 1496-1547. https://doi.org/10.3390/12071496

Atif, M.J., Amin, B., Ghani, M.I., Ali, M., Zhang, S. and Cheng, Z. (2020). Effect of photoperiod and temperature on garlic (Allium sativum L.) bulbing and selected endogenous chemical factors. Environmental and Experimental Botany, 180, 104250. https://doi.org/https://doi.org/10.1016/ j.envexpbot.2020.104250

Batiha, E.-S.G., Beshbishy, A.M., Wasef, L.G., Elewa, Y.H., Al-Sagan, A.A., El-Hack, A., Mohamed, E., Taha, A.E., Abd-Elhakim, Y.M. and Devkota, H.P. (2020). Chemical Constituents and Pharmacological Activities of Garlic (Allium sativum L.): A Review. Nutrients, 12(3), 872. https://doi.org/10.3390/ nu12030872

Capasso, A. (2013). Antioxidant action and therapeutic efficacy of Allium sativum L. Molecules, 18(1), 690 700. https://doi.org/10.3390/molecules 18010690

Cardelle-Cobas, A., Moreno, F.J., Corzo, N., Olano, A. and Villamiel, M. (2005). Assessment of Initial Stages of Maillard Reaction in Dehydrated Onion and Garlic Samples. Journal of Agricultural and Food Chemistry, 53(23), 9078-9082. https:// doi.org/10.1021/jf051302t

Catanzaro, M., Corsini, E., Rosini, M., Racchi, M. and Lanni, C. (2018). Immunomodulators Inspired by Nature: A Review on Curcumin and Echinacea. Molecules, 23(11), 2778. https://doi.org/10.3390/ molecules 23112778

Ciric, A., Krajnc, B., Heath, D. and Ogrinc, N. (2020). Response surface methodology and artificial neural network approach for the optimization of ultrasoundassisted extraction of polyphenols from garlic. Food and Chemical Toxicology, 135, 110976. https:// doi.org/https://doi.org/10.1016/j.fct.2019.110976

Collin, F. (2019). Chemical basis of reactive oxygen species reactivity and involvement in neurodegenerative diseases. International Journal of
Molecular Sciences, 20(10), 2407. https:// doi.org/10.3390/ijms20102407

De Greef, D., Barton, E.M., Sandberg, E.N., Croley, C.R., Pumarol, J., Wong, T.L., Das, N. and Bishayee, A. (2020). Anticancer potential of garlic and its bioactive constituents: A systematic and comprehensive review. Seminars in Cancer Biology, 73, 219-264. https://doi.org/https://doi.org/10.1016/ j.semcancer.2020.11.020

Dillon, S.A., Burmi, R.S., Lowe, G.M., Billington, D. and Rahman, K. (2003). Antioxidant properties of aged garlic extract: An in vitro study incorporating human low density lipoprotein. Life Sciences, 72 (14), 1583-1594. https://doi.org/10.1016/S00243205(02)02475-X

Dumont, E., Ogra, Y., Vanhaecke, F., Suzuki, K.T. and Cornelis, R. (2006). Liquid chromatography-mass spectrometry (LC-MS): A powerful combination for selenium speciation in garlic (Allium sativum). Analytical and Bioanalytical Chemistry, 384(5), 1196-1206. https://doi.org/10.1007/s00216-005$0272-6$

Dunnick, J.K. and Halley, J.R. (1992). Toxicity and carcinogenicity studies of quercetin, a natural component of foods. Toxicological Sciences, 19(3), 423-431. https://doi.org/10.1093/toxsci/19.3.423

Durairaj, S., Srinivasan, S. and Lakshmanaperumalsamy, P. (2009). In vitro Antibacterial Activity and Stability of Garlic Extract at Different $\mathrm{pH}$ and Temperature. Electric Journal of Biology, 5(1), 510.

Elmore, S. (2007). Apoptosis: a review of programmed cell death. Toxicologic Pathology, 35(4), 495-516. https://doi.org/10.1080/01926230701320337

Fei, M.L.I., Tong, L.I., Wei, L.I. and De Yang, L. (2015). Changes in antioxidant capacity, levels of soluble sugar, total polyphenol, organosulfur compound and constituents in garlic clove during storage. Industrial Crops and Products, 69, 137142. https://doi.org/10.1016/j.indcrop.2015.02.021

Feng, Y., Wu, B., Yu, X., Yagoub, A.E.A., Sarpong, F. and Zhou, C. (2018). Effect of catalytic infrared dryblanching on the processing and quality characteristics of garlic slices. Food Chemistry, 266, 309-316. https://doi.org/https://doi.org/10.1016/ j.foodchem.2018.06.012

Feng, Y., Xu, B., ElGasim A. Yagoub, A., Ma, H., Sun, Y., Xu, X., Yu, X. and Zhou, C. (2020). Role of drying techniques on physical, rehydration, flavor, bioactive compounds and antioxidant characteristics of garlic. Food Chemistry, 343, 128404. https:// doi.org/https://doi.org/10.1016/ 
j.foodchem.2020.128404

Ferioli, F., Giambanelli, E., D'Alessandro, V. and D'Antuono, L.F. (2020). Comparison of two extraction methods (high pressure extraction vs. maceration) for the total and relative amount of hydrophilic and lipophilic organosulfur compounds in garlic cloves and stems. An application to the Italian ecotype "Aglio Rosso di Sulmona" (Sulmona Red Garlic). Food Chemistry, 312, 126086. https:// doi.org/https://doi.org/10.1016/

j.foodchem.2019.126086

Fernandes, S., Gois, A., Mendes, F., Perestrelo, R., Medina, S. and Câmara, J.S. (2020). Typicality assessment of onions (Allium cepa) from different geographical regions based on the volatile signature and chemometric tools. Foods, 9(3), 375. https:// doi.org/10.3390/foods 9030375

Fesseha, H. and Goa, E. (2019). Therapeutic Value of Garlic (Allium sativum): A Review. Advances in Food Technology and Nutrition Sciences - Open Journal, 5(3), 107-117. https://doi.org/10.17140/ aftnsoj-5-162

Formica, J.V. and Regelson, W. (1995). Review of the biology of quercetin and related bioflavonoids. Food and Chemical Toxicology, 33(12), 1061-1080. https://doi.org/10.1016/0278-6915(95)00077-1

González, E.A. and Nazareno, M.A. (2011). Antiradical action of flavonoid-ascorbate mixtures. $L W T$ - Food Science and Technology, 44(2), 558-564. https:// doi.org/10.1016/j.lwt.2010.09.017

Gupta, D. (2015). Methods for determination of antioxidant capacity: A review. International Journal of Pharmaceutical Sciences and Research, 6 (2), 546-566. https://doi.org/10.13040/IJPSR.09758232.6(2).546-66

Gutierrez, M. del C., Rocca, P.D., De Seta, E. and Reina, F. (2014). Evaluation of the Antioxidant Activity of Ethanolic Extracts of Some Varieties of Onions. Journal of Agricultural Chemistry and Environment, 3(2), 26-34. https://doi.org/10.4236/ jacen.2014.32b005

Hadji, I., Marzouki, M.N., Ferraro, D., Fasano, E., Majdoub, H., Pani, G. and Limam, F. (2007). Purification and characterization of a $\mathrm{Cu}, \mathrm{Zn}-\mathrm{SOD}$ from garlic (Allium sativum L.). Antioxidant effect on tumoral cell lines. Applied Biochemistry and Biotechnology, 143(2), 129-141. https:// doi.org/10.1007/s12010-007-0042-3

Handa, S.S., Khanuja, S.P.S., Longo, G. and Rakesh, D.D. (2008). Extraction technologies for medicinal technologies and aromatic plants. In International Centre for Science and High Technology. Trieste
(Italy): United Nations Industrial Development Organization and the International Centre for Science and High Technology.

Higuchi, O., Tateshita, K. and Nishimura, H. (2003). Antioxidative Activity of Sulfur-Containing Compounds in Allium Species for Human LowDensity Lipoprotein (LDL) Oxidation in Vitro. Journal of Agricultural and Food Chemistry, 51(24), 7208-7214. https://doi.org/10.1021/jf034294u

Hosseinzade, A., Sadeghi, O., Naghdipour Biregani, A., Soukhtehzari, S., Brandt, G.S. and Esmaillzadeh, A. (2019). Immunomodulatory Effects of Flavonoids: Possible Induction of $\mathrm{T} \mathrm{CD} 4+$ Regulatory Cells Through Suppression of mTOR Pathway Signaling Activity. Frontiers in Immunology, 10, 51. https:// doi.org/10.3389/fimmu.2019.00051

Ichikawa, M., Ide, N., Yoshida, J., Yamaguchi, H. and Ono, K. (2006). Determination of seven organosulfur compounds in garlic by high-performance liquid chromatography. Journal of Agricultural and Food Chemistry, 54(5), 1535-1540. https:// doi.org/10.1021/jf051742k

Ilić, D., Nikolić, V., Stanković, M., Nikolić, L., Stanojević, L., Mladenović-Ranisavljević, I. and Šmelcerović, A. (2012). Transformation of Synthetic Allicin: The Influence of Ultrasound, Microwaves, Different Solvents and Temperatures, and the Products Isolation. The Scientific World Journal, 2012, 561823. https://doi.org/10.1100/2012/561823

Indiarto, R., Pranoto, Y., Santoso, U. and Supriyanto. (2019). In vitro antioxidant activity and profile of polyphenol compounds extracts and their fractions on cacao beans. Pakistan Journal of Biological Sciences, 22(1), 34-44. https://doi.org/10.3923/ pjbs.2019.34.44

Kamel, A. and Saleh, M. (2000). Recent studies on the chemistry and biological activities of the organosulfur compounds of garlic (Allium sativum). Studies in Natural Products Chemistry, 23, 455-485. https://doi.org/10.1016/S1572-5995(00)80135-0

Kim, J.B. and Cheong, S.H. (2015). Volatile organosulfur and nutrient compounds derived from garlic (Allium sativum) according to cultivating areas and processing methods. Research Journal of Pharmaceutical, Biological and Chemical Sciences, 6(6), 978-984.

Kneck, Å., Fagerberg, I., Eriksson, L.E. and Lundman, B. (2014). Living with diabetes-development of learning patterns over a 3-year period. International Journal of Qualitative Studies on Health and WellBeing, 9(1), 24375. https://doi.org/10.3402/ qhw.v9.24375 
Kumar, S. and Pandey, A.K. (2013). Chemistry and Biological Activities of Flavonoids: An Overview. The Scientific World Journal, 2013, 162750. https:// doi.org/10.1155/2013/162750

Lee, H.J., Suh, H.J., Han, S.H., Hong, J. and Choi, H.-S. (2016). Optimization of Extraction of Cycloalliin from Garlic (Allium sativum L.) by Using Principal Components Analysis. Preventive Nutrition and Food Science, 21(2), 138-146. https:// doi.org/10.3746/pnf.2016.21.2.138

Lee, H.J., Suh, H.J. and Park, Y. (2013). Utilization of hydrolytic enzymes for the extraction of cycloalliin from garlic (Allium sativum L.). Process Biochemistry, 48(7), 1111-1117. https://doi.org/ https://doi.org/10.1016/j.procbio.2013.05.008

Li, F., Li, Q., Wu, S. and Tan, Z. (2017). Salting-out extraction of allicin from garlic (Allium sativum L.) based on ethanol/ammonium sulfate in laboratory and pilot scale. Food Chemistry, 217, 91-97. https:// doi.org/https://doi.org/10.1016/

j.foodchem.2016.08.092

Lin, S., Zhang, G., Liao, Y., Pan, J. and Gong, D. (2015). Dietary Flavonoids as Xanthine Oxidase Inhibitors: Structure-Affinity and Structure-Activity Relationships. Journal of Agricultural and Food Chemistry, 63(35), 7784-7794. https:// doi.org/10.1021/acs.jafc.5b03386

Liu, J., Ji, F., Chen, F., Guo, W., Yang, M., Huang, S., Zhang, F. and Liu, Y. (2018). Determination of garlic phenolic compounds using supercritical fluid extraction coupled to supercritical fluid chromatography/tandem mass spectrometry. Journal of Pharmaceutical and Biomedical Analysis, 159, 513-523. https://doi.org/https://doi.org/10.1016/ j.jpba.2018.07.020

Locatelli, D.A., Altamirano, J.C., González, R.E. and Camargo, A.B. (2015). Home-cooked garlic remains a healthy food. Journal of Functional Foods, 16, 18. https://doi.org/10.1016/j.jff.2015.04.012

Locatelli, D.A., Nazareno, M.A., Fusari, C.M. and Camargo, A.B. (2017). Cooked garlic and antioxidant activity: Correlation with organosulfur compound composition. Food Chemistry, 220, 219 224. https://doi.org/10.1016/j.foodchem.2016.10.001

Molyneux, P. (2004). The Use of the Stable Free Radical Diphenylpicryl-hydrazyl (DPPH) for Estimating Antioxidant Activity. Songklanakarin Journal of Science and Technology, 26(2), 211-219. https:// doi.org/10.1287/isre.6.2.144

Nencini, C., Menchiari, A., Franchi, G.G. and Micheli, L. (2011). In vitro Antioxidant Activity of Aged Extracts of some Italian Allium Species. Plant Foods for Human Nutrition, 66(1), 11-16. https:// doi.org/10.1007/s11130-010-0204-2

Nicoli, M.C., Anese, M. and Parpinel, M. (1999). Influence of processing on the antioxidant properties of fruit and vegetables. Trends in Food Science and Technology, 10(3), 94-100. https://doi.org/10.1016/ S0924-2244(99)00023-0

Noda, Y., Asada, C., Sasaki, C., Hashimoto, S. and Nakamura, Y. (2013). Extraction method for increasing antioxidant activity of raw garlic using steam explosion. Biochemical Engineering Journal, 73, 1-4. https://doi.org/https://doi.org/10.1016/ j.bej.2013.01.013

Omar, S.H. and Al-Wabel, N.A. (2010). Organosulfur compounds and possible mechanism of garlic in cancer. Saudi Pharmaceutical Journal: SPJ: The Official Publication of the Saudi Pharmaceutical Society, 18(1), 51-58. https://doi.org/10.1016/ j.jsps.2009.12.007

Panche, A.N., Diwan, A.D. and Chandra, S.R. (2016). Flavonoids: an overview. Journal of Nutritional Science, 5, e47. https://doi.org/10.1017/jns.2016.41

Parisi, M.G., Moreno, S. and Fernández, G. (2008). Isolation and characterization of a dual function protein from Allium sativum bulbs which exhibits proteolytic and hemagglutinating activities. Plant Physiology and Biochemistry, 46(4), 403-413. https://doi.org/10.1016/j.plaphy.2007.11.003

Pedraza-Chaverrí, J., Arriaga-Noblecía, G. and MedinaCampos, O.N. (2007). Hypochlorous acid scavenging capacity of garlic. Phytotherapy Research, 21(9), 884-888. https://doi.org/10.1002/ ptr. 2175

Phan, L.M., Yeung, S.-C.J. and Lee, M.-H. (2014). Cancer metabolic reprogramming: importance, main features, and potentials for precise targeted anticancer therapies. Cancer Biology and Medicine, 11 (1), 1-19. https://doi.org/10.7497/j.issn.20953941.2014.01.001

Pokorný, J., Yanishlieva, N. and Gordon, M. (Eds.) (2001). Antioxidants in food. Practical applications. Cambridge, UK: Woodhead.

Ponce, A.M., Blanco, S.E., Molina, A.S., GarcíaDomenech, R. and Gálvez, J. (2000). Study of the Action of Flavonoids on Xanthine-Oxidase by Molecular Topology. Journal of Chemical Information and Computer Sciences, 40(4), 10391045. https://doi.org/10.1021/ci000020k

Prasonto, D., Riyanti, E. and Gartika, M. (2017). Uji Aktivitas Antioksidan Ekstrak Bawang Putih (Allium sativum). ODONTO: Dental Journal, 4, 122-128. https://doi.org/10.30659/odj.4.2.122-128 [In Bahasa 
Indonesia].

Queiroz, Y.S., Ishimoto, E.Y., Bastos, D.H.M., Sampaio, G.R. and Torres, E.A.F.S. (2009). Garlic (Allium sativum L.) and ready-to-eat garlic products: In vitro antioxidant activity. Food Chemistry, 115(1), 371374. https://doi.org/10.1016/j.foodchem.2008.11.105

Rahal, A., Kumar, A., Singh, V., Yadav, B., Tiwari, R., Chakraborty, S. and Dhama, K. (2014). Oxidative stress, prooxidants, and antioxidants: the interplay. BioMed Research International, 2014, 761264. https://doi.org/10.1155/2014/761264

Rahmawati, D., Andika, D. and Fortunata, S.A. (2019). Evaluation of Phytochemical Activities of Aqueous and Ethanolic Garlic Peel Extract. Journal of Functional Food and Nutraceutical, 1(1), 41-46. https://doi.org/10.33555/jffn.v1i1.20

Ramirez, D.A., Locatelli, D.A., González, R.E., Cavagnaro, P.F. and Camargo, A.B. (2017). Analytical methods for bioactive sulfur compounds in Allium: An integrated review and future directions. Journal of Food Composition and Analysis, 61, 4-19. https://doi.org/https:// doi.org/10.1016/j.jfca.2016.09.012

Rezaharsamto, B. and Subroto, E. (2019). A Review on Bioactive Peptides Derived From Various Sources Of Meat And Meat By-Products. International Journal of Scientific and Technology Research, 8 (12), 3151-3156.

Ricciutelli, M., Nzekoue, F.K., Caprioli, G., Sagratini, G., Alesi, A., Vici, G. and Polzonetti, V. (2020). Study of the effect of marination treatment on garlic bioactive compounds through an innovative HPLCDAD-MS method for alliin and curcuminoids analysis. LWT-Food Science and Technology, 131, 109788. https://doi.org/https://doi.org/10.1016/ j.lwt.2020.109788

Rizwani, G.H. and Shareef, H. (2011). Genus Allium: The Potential Nutritive and Therapeutic Source. Journal of Pharmacy and Nutrition Sciences, 1(2), 158-165. https://doi.org/10.6000/19275951.2011 .01 .02 .11

Santos, C.M.M. and Silva, A.M.S. (2020). The Antioxidant Activity of Prenylflavonoids. Molecules (Basel, Switzerland), 25(3), 696. https:// doi.org/10.3390/molecules25030696

Sekara, A., Pokluda, R., Del Vacchio, L., Somma, S. and Caruso, G. (2017). Interactions among genotype, environment and agronomic practices on production and quality of storage onion (Allium cepa L.) - A review. Horticultural Science, 44(1), 21-42. https:// doi.org/10.17221/92/2015-HORTSCI

Shahidi, F. and Zhong, Y. (2015). Measurement of antioxidant activity. Journal of Functional Foods, 18 (Part B), 757-781. https://doi.org/https:// doi.org/10.1016/j.jff.2015.01.047

Shang, A., Cao, S.-Y., Xu, X.-Y., Gan, R.-Y., Tang, G.Y., Corke, H., Mavumengwana, V. and Li, H.-B. (2019). Bioactive Compounds and Biological Functions of Garlic (Allium sativum L.). Foods (Basel, Switzerland), 8(7), 246. https:// doi.org/10.3390/foods 8070246

Sharma, P., Jha, A.B., Dubey, R.S. and Pessarakli, M. (2012). Reactive Oxygen Species, Oxidative Damage, and Antioxidative Defense Mechanism in Plants under Stressful Conditions. Journal of Botany, 2012, 217037. https://doi.org/10.1155/2012/217037

Sharma, P., Sharma, S.R., Dhall, R.K., Mittal, T.C. and Bhatia, S. (2020). Physio-chemical behavior of $\gamma$ irradiated garlic bulbs under ambient storage conditions. Journal of Stored Products Research, 87, 101629. https://doi.org/https://doi.org/10.1016/ j.jspr.2020.101629

Sharma, P., Sharma, S.R., Dhall, R.K., Mittal, T.C. and Kumar, S. (2021). Variation in quality and acceptability of minimally processed garlic in response to $\gamma$-irradiation and packaging during refrigerated storage. Radiation Physics and Chemistry, 180, 109193. https://doi.org/https:// doi.org/10.1016/j.radphyschem.2020.109193

Sotler, R., Poljšak, B., Dahmane, R., Jukić, T., Pavan Jukić, D., Rotim, C., Trebše, P. and Starc, A. (2019). Prooxidant Activities of Antioxidants and Their Impact on Health. Acta Clinica Croatica, 58(4), 726 -736. https://doi.org/10.20471/acc.2019.58.04.20

Subroto, E. and Indiarto, R. (2020). Bioactive monolaurin as an antimicrobial and its potential to improve the immune system and against COVID-19: a review. Food Research, 4(6), 2355-2365. https:// doi.org/10.26656/fr.2017.4(6).324

Tomšik, A., Pavlić, B., Vladić, J., Cindrić, M., Jovanov, P., Sakač, M., Mandić, A. and Vidović, S. (2017). Subcritical water extraction of wild garlic (Allium ursinum L.) and process optimization by response surface methodology. The Journal of Supercritical Fluids, 128, 79-88. https://doi.org/https:// doi.org/10.1016/j.supflu.2017.05.012

Tsai, K.D., Lin, B.R., Perng, D.S., Wei, J.C., Yu, Y.W. and Cherng, J.M. (2011). Immunomodulatory effects of aqueous extract of Ocimum basilicum (Linn.) and some of its constituents on human immune cells. Journal of Medicinal Plants Research, 5(10), 18731883.

Ulfah, M., Cahyani, V.S.N. and Kinasih, I. (2017). Pengaruh Pemberian Seduhan Teh Daun Sirsak (Annona muricata L.) terhadap Aktivitas Fagositosis 
Sel Makrofag dan Proliferasi Sel Limfosit Mencit Galur Balb/C yang Diinduksi Vaksin Hepatitis B. Momentum, 13(2), 63-71. https://doi.org/10.36499/ jim.v13i2.2039

Vaseeharan, B. and Thaya, R. (2014). Medicinal plant derivatives as immunostimulants: an alternative to chemotherapeutics and antibiotics in aquaculture. Aquaculture International, 22(3), 1079-1091. https://doi.org/10.1007/s10499-013-9729-3

Weinberg, D.S., Manier, M.L., Richardson, M.D. and Haibach, F.G. (1993). Identification and quantification of organosulfur compliance markers in a garlic extract. Journal of Agricultural and Food Chemistry, 41(1), 37-41. https://doi.org/10.1021/ jf00025a008

Yilmaz, Y. and Toledo, R. (2005). Antioxidant activity of water-soluble Maillard reaction products. Food Chemistry, 93(2), 273-278. https://doi.org/10.1016/ j.foodchem.2004.09.043

Yu, T.-H., Lin, L.-Y. and Ho, C.-T. (1994). Volatile Compounds of Blanched, Fried Blanched, and Baked Blanched Garlic Slices. Journal of Agricultural and Food Chemistry, 42(6), 1342-1347. https:// doi.org/10.1021/jf00042a018

Yu, T.H., Wu, C.M. and Ho, C.T. (1993). Volatile compounds of deep-oil fried, microwave-heated and oven-baked garlic slices. Journal of Agricultural and Food Chemistry, 41(5), 800-805. https:// doi.org/10.1021/jf00029a023

Yu, X., Lim, C.Y.X., Dong, B. and Hadinoto, K. (2020). Development of magnetic solid phase extraction platform for the purification of bioactive $\gamma$-glutamyl peptides from garlic (Allium sativum). LWT - Food Science and Technology, 127, 109410. https:// doi.org/https://doi.org/10.1016/j.lwt.2020.109410

Zang, J., Wang, D. and Zhao, G. (2013). Mechanism of discoloration in processed garlic and onion. Trends in Food Science and Technology, 30(2), 162-173. https://doi.org/https://doi.org/10.1016/ j.tifs.2013.01.008 